УДК 697.94.(075)

В.Й. Лабай, Д.І. Гарасим

Національний університет «Львівська політехніка», вул. Ст. Бандери, 12, Львів, 79013, Україна

\title{
ВПЛИВ КОЕФІЦІЄНТА ТРАНСФОРМАЦІЇ ХОЛОДИЛЬНОЇ МАШИНИ НА ЕКСЕРГЕТИ- ЧНИЙ ККД СИСТЕМИ КОНДИЦІЮВАННЯ ПОВІТРЯ ЧИСТОГО ПРИМІЩЕННЯ
}

\begin{abstract}
У статті використана авторська інновачійна математична дослідницька модель центральної прямотечійної системи кондиціювання повітря чистого приміщзення. Мета моделі - комп 'ютерне оцінювання ексергетичної ефективності вибраної системи кондиціювання залежно від різних факторів, щзо впливають на ї̈ роботу, зокрема коефіцієнта трансформації EER холодильної машини. Завдяки иій моделі отримано залежність ексергетичного ККД вибраної системи кондиціювання від коефіцієнта трансформації EER ї̈ холодильної машини за різних параметрів зовнішнього і внутрішнього повітря та різниці температур внутрішнього $і$ припливного повітря.
\end{abstract}

Ключові слова: Ексергетичний баланс - Системи кондиціювання повітря - Чисті приміщення - Ексергетична ефективність - Коефіцієнт трансформації ЕЕR

В.И. Лабай, Д.И. Гарасым

Национальный университет «Львовская политехника», ул. Ст. Бандеры, 12, Львов, 79013, Украина

\section{ВЛИЯНИЕ КОЭФФИЦИЕНТА ТРАНСФОРМАЦИИ ХОЛОДИЛЬНОЙ МАШИНЫ НА ЕКСЕРГЕТИЧЕСКИЙ КПД СИСТЕМЫ КОНДИЦИОНИРОВАНИЯ ВОЗДУХА ЧИСТОГО ПОМЕЩЕНИЯ}

\begin{abstract}
В статье использована авторская инновачионная математическая исследовательская модель центральной прямоточной системы кондиционирования воздуха чистого помещения. Цель модели - компьютерная оченка эксергетической эффективности избранной системы кондиционирования в зависимости от разных факторов, какие влияют на ее работу, в частности коэффициента трансформации EЕR холодильной машины. Благодаря этой модели получено зависимость эксергетического КПД избранной системь кондииионирования от коэффициента трансформации EER ее холодильной машины при разных параметрах наружного и внутреннего воздуха и разности температур внутреннего и приточного воздуха.

Ключевые слова: Эксергетический баланс - Системы кондиционирования воздуха Чистые помещения - Эксергетическая эффективность - Коэффициент трансформаџии EER
\end{abstract}

DOI: $10.15673 / 0453-8307.2 / 2015.39348$

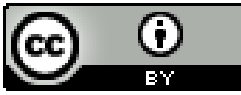

\section{I. ВСТУП}

Ексергетичний метод $є$ універсальним способом термодинамічного дослідження різних процесів перетворення енергії у енерготехнологічних системах (ЕTC), до яких належить система кондиціювання повітря чистого приміщення. Виконання ексергетичного аналізу для ЕТС дає можливість встановити вплив різних елементів ЕТС на їі роботу та завдяки цьому підвищити ефективність роботи ЕТС у цілому. Це і є основною метою ексергетичного методу аналізу ЕТС. Використання ексергетичного методу аналізу обгрунтоване у роботах Р.К. Клаузіуса, Дж.В. Гіббса, Ж. Гюі, А. Стодоли, Я. Шаргута та Р. Петели [6-10].
Ексергетичний баланс для даної ЕТС, тобто системи кондиціювання повітря чистого приміщення, має такий вигляд:

$$
E_{\mathrm{BX}}=E_{\mathrm{Bux}}+\sum_{i=1}^{n} D_{i}, \mathrm{BT},
$$

або

$$
\sum_{i=1}^{n} D_{i}=E_{\mathrm{Bх}}-E_{\mathrm{вих}}, \mathrm{BT},
$$

де $E_{\mathrm{Bx}}-$ ексергія приводу СКП, яка витрачається на підтримання процесу, Вт; $E_{\text {вих }}-$ приріст ексергії повітря у кондиціонованому приміщенні, Вт; $\sum_{i=1}^{n} D_{i}$ - сума ексергетичних втрат ЕТС, Вт. 
Ексергетичний баланс будь-якої ЕТС складають на основі її принципової схеми (рисунок 1).

Вочевидь, досконалість ЕТС та Пї елементів тим вища, чим вищий ексергетичний ККД, який визначають з ексергетичного балансу, а саме [6-10, $12,13,15-20]$ :

$$
\eta_{\mathrm{e}}=\frac{E_{\mathrm{Bux}}}{E_{\mathrm{Bx}}} .
$$

Розрахунок ексергетичного ККД ЕТС створює умови для вирішення питання економії паливно-енергетичних ресурсів [7, 8, 11-13, 16, 18-20].

Отже, ексергетичний ККД ЕТС обраховують за формулою (3), в якій чисельник є корисним ексергетичним ефектом, а знаменник - затратами ексергії, а значить ексергетичний ККД можна визначати за формулою:

$$
\eta_{\mathrm{e}}=\frac{E_{\text {вих }}}{E_{\text {вих }}+\sum_{i=1}^{n} D_{i}}=\frac{E_{\mathrm{e} \phi}}{E_{\text {затр }}} .
$$

Ефективність роботи будь-якої системи кондиціювання повітря (СКП) залежить від енергоефективності холодильної машини (XM), яка іiі обслуговує та споживає електричну енергію для зменшення теплоти припливного у приміщення повітря. А це означає, що головна мета вибору певної холодильної машини для СКП - досягти максимальної холодопродуктивності за мінімального енергоспоживання. Тому для оцінки енергоефективності холодильних машин введений коефіцієнт енергетичної ефективності EER (Energy Efficiency Rate), або коефіцієнт трансформації, який дорівнює відношенню холодопродуктивності до повної споживаної потужності за розрахункових (стандартних) умов роботи:

$$
E E R=\frac{Q_{\mathrm{x}}}{N_{\text {сп }}}
$$

де $Q_{\mathrm{x}}-$ холодопродуктивність $\mathrm{XM}, \mathrm{Bт} ; N_{\text {сп }}-$ споживана потужність ХМ, Вт.

У даний час $E E R$ для XМ може бути від 1,8 до 5. Для позначення енергоефективності XМ $€$ сім категорій, які позначаються буквами від «A» (кращої) до «G» (гіршої). ХМ категорії «A» $E E R \geq 3,2$, а категорії «G» $E E R<2,2$.

Тому метою даної роботи було дослідити залежність ексергетичного ККД $\eta_{\mathrm{e}}$ центральної прямотечійної СКП чистого приміщення від коефіцієнта трансформації EER XM.

\section{II. ОПИСАННЯ ОБ'ЄКТУ АНАЛІЗУ ТА ІННО- ВАЦІЙНОЇ ДОСЛІДНИЦЬКОЇ МОДЕЛІ}

Метою кондиціювання повітря є підтримання у деякому обмеженому просторі (у даному випадку у чистому приміщенні) певних параметрів повітря. Звичайно регулюванню підлягає температуpa $t_{\mathrm{B}}$ і відносна вологість $\varphi_{\mathrm{B}}$ повітря, а у чистих приміщеннях це додатково й концентрація пили-

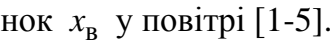

Розглянемо центральну прямотечійну СКП чистого приміщення, схематично зображену на рисунку 1. Робота такої системи у теплий період року (ТПР) залежить від параметрів навколишнього (зовнішнього) середовища, тобто від температури і відносної вологості повітря зовнішнього середовища, а також прийнятих внутрішньої та припливної температур повітря у приміщенні. Повітря 3 навколишнього середовища через повітрозабірну шахту 6 забирається центральним кондиціонером, очищається у фільтрі зовнішнього повітря 7, далі проходить через повітронагрівник I підігрівання 8, охолоджується та осушується за політропою у камері зрошення 9, до якої надходить холодна вода 3 холодильної машини, підігрівається у повітронагрівнику II підігрівання 10, а відтак вентиляторним агрегатом 12 подається у чисте приміщення через фільтр припливного повітря 11 у центральному кондиціонері, припливні повітропроводи 5 та фільтри припливного повітря 4 на вході у приміщення.

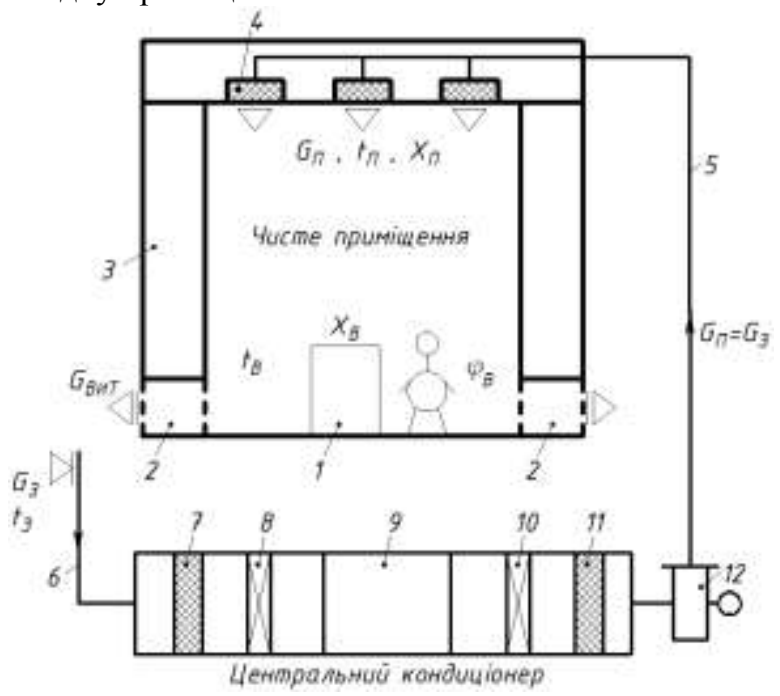

Рисунок 1 - Принципова схема цчентральної прямотечійної системи кондиціювання повітря чистого приміщення: 1 - технологічне обладнання; 2 - витяжсні канали; 3 - илюзові приміщення; 4 - фільтри припливного повітря у приміщення; 5 - припливний повітропровід; 6 - повітрозабірна шахта; 7 - фільтр зовнішнього повітря; 8 - повітронагрівник I підігрівання; 9 - камера зрошення, до якої холодна вода надходить з холодильної мачини; 10 повітронагрівник II підігрівання;

11 - фільтр припливного повітря у кондиціонері; 12 - вентиляторний агрегат

Робота досліджуваної СКП відбувалась у ТПР, коли вологовміст $d_{\text {в }}<d_{3}$ і температура $t_{\text {в }}<t_{3}$. На рисунку 2 наведена у системі координат $I, d$ послідовність зміни параметрів повітря, яке проходить через різне обладнання центральної прямотечійної системи кондиціювання повітря чистого приміщення. Досліджувана СКП мала масову продуктивність СКП $G=10000$ кг/год, параметри зовнішнього повітря у дослідженнях змінювались 
так: $t_{3}=26 ; 30 ; 34 ; 38 ; 42^{\circ} \mathrm{C}$; відносна вологість $\left.\varphi_{3}=49 ; 43 ; 38 ; 32 ; 27 \%\right)$, барометричний тиск $p_{3}=1010$ гПа; параметри внутрішнього повітря відповідно $-t_{\text {в }}=23 ; 26 ; 27 ; 28 ; 30^{\circ} \mathrm{C} ; \varphi_{\mathrm{B}}=50 \%$; різниця температур між внутрішнім і припливним повітрям залежно від теплонадлишків у чистому приміщенні $\Delta t_{\Pi}=t_{\mathrm{B}}-t_{\Pi}=1,5 ; 2,5 ; 3,5 ; 5,0 ; 6,0^{\circ} \mathrm{C}$.

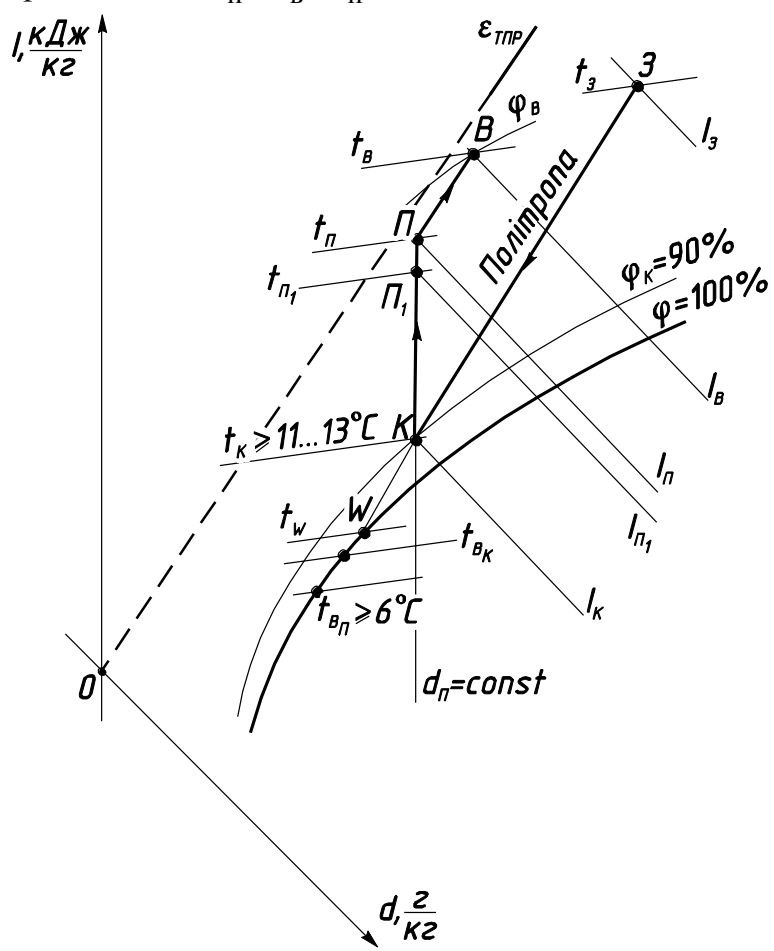

Рисунок 2 - Зображення процесів зміни стану вологого повітря у прямотечійній СКП в ТПР на I-d-діаграмі: $3 \boldsymbol{K}$ - проиес політропного оброблення (охолодження та осушування) повітря $G_{\text {к.зр }}=G_{\text {П }}$ у камері зрошення;

$\boldsymbol{K \Pi}_{1}$ - прочес нагрівання повітря $G_{\Pi}$ у повітронагрівнику II підігрівання;

$\boldsymbol{\Pi}_{\mathbf{1}} \boldsymbol{\Pi}$ - підігрівання повітря $G_{\Pi}$ на $1^{\circ} \mathrm{C}$ увентиляторі та припливному повітропроводі; - прочес асимілячії тепло- $і$ вологонадлишків в чистому приміщенні припливним повітрям $G_{\Pi}$ з кондииіонера

Послідовність змін, які відбувались з вологим повітрям, що проходило через різне обладнання системи кондиціювання повітря, наведені на рисунку 2. Побудова на $I-d$ - діаграмі виконана згідно 3 [11]. Параметри повітря у характерних точках процесу (рисунок 2) встановлювались за прийнятими значеннями параметрів для зовнішнього повітря та підраховувались на запропонованій інноваційній математичній дослідницькій моделі за відомими аналітичними залежностями для вологого повітря [19, 20].

Разом $з$ тим завданням дослідницької моделі було комп'ютерне оцінювання ексергетичної ефективності вибраної системи кондиціювання залежно від коефіцієнта трансформації $E E R$ iї холодильної машини за різних параметрів зовнішнього і внутрішнього повітря та різниці температур внутрішнього і припливного повітря. Завдяки цій моделі отримано результати досліджень, які зведені в таблицю 1.

Ексергетичний ККД, який характеризує ефективність роботи центральної прямотечійної системи кондиціювання чистого приміщення у ТПР, визначали за формулою (4), у якій $E_{\text {вих }}=E_{\Pi}-E_{\mathrm{B}}$ - зменшення ексергії кондиціонованого повітря у чистому приміщенні (корисно використана ексергія), Вт; $E_{\Pi}$ і $E_{\mathrm{B}}-$ відповідно, ексергія припливного і внутрішнього повітря у чистому приміщенні, Вт; $D_{\text {к.зр }}=E_{\mathrm{K}}-E_{3}-$ втрата ексергії повітря у камері зрошення, Вт; $E_{\mathrm{K}}$ і $E_{3}-$ відповідно, ексергія оброблюваного повітря на виході та вході (зовнішнього повітря) у камеру зрошення, Вт; $D_{\text {нагр }}=E_{\mathrm{K}}-E_{\Pi_{1}}-$ втрата ексергії повітря у повітронагрівнику II підігрівання, Вт; $E_{\mathrm{K}}$ і $E_{\Pi_{1}}-$ відповідно, ексергія оброблюваного повітря на вході та виході з повітронагрівника II підігрівання, Вт; $D_{\text {вит }}=E_{\mathrm{B}}-E_{3}-$ втрата ексергії з витяжним кондиціонованим повітрям з чистого приміщення, Вт; $D_{\text {х.в }}=N_{\text {сп }}^{\text {х.в }}-$ втрата ексергії 3 насосом холодної води для камери зрошення, Вт; $D_{\text {г.в }}=N_{\text {сп }}^{\text {г.в }}-$ втрата ексергії насосом гарячої води для повітронагрівника II підігрівання, Вт; $D_{\text {вент }}=N_{\text {сп }}^{\text {вент }}-$ втрата ексергії 3 двигуном вентилятора прийнятого центрального кондиціонера, Вт; $D_{\mathrm{XM}}=N_{\mathrm{cп}}^{\mathrm{XM}}$ - втрата ексергії 3 холодильною машиною для центрального кондиціонера, Вт. Отже, загальні втрати ексергії у вибраній СКП визначали так:

$$
\begin{aligned}
& \sum_{i=1}^{n} D_{i}=D_{\text {к.зр }}+D_{\text {нагр }}+D_{\text {вит }}+ \\
& +D_{\text {Х.в }}+D_{\text {г.в }}+D_{\text {вент }}+D_{\text {ХМ }}, \text { ВТ. }
\end{aligned}
$$

Як визначали величини, що входять у формулу (4) подано у $[19,20]$.

\section{III. РЕЗУЛЬТАТИ ДОСЛІДНИЦЬКОЇ РОБОТИ}

На основі досліджень, проведених нами на інноваційній математичній моделі для вказаної СКП, отримано залежності ексергетичного ККД $\eta_{\mathrm{e}}$ від коефіцієнта трансформації $E E R$ iï холодильної машини за різних параметрів зовнішнього $\left(t_{3}, \varphi_{3}\right)$ і внутрішнього $\left(t_{\mathrm{B}}, \varphi_{\mathrm{B}}\right)$ повітря та різниці температур $\Delta t_{\text {п }}$ внутрішнього і припливного повітря, які подані на рисунку 3 і у таблиці 1.

Аналізуючи отримані дані досліджень на рисунку 3 і у таблиці 1, можна дійти таких висновків. Загальне зростання коефіцієнта трансформації $E E R$ від 2,8 до 4,4, тобто в 1,57 рази, призводить до зростання значення ексергетичного ККД $\eta_{\mathrm{e}}$ за різних умов проведення досліджень від 1,31 до 1,34 рази або 
на 31-34\%. Варто також зауважити (рисунок 3 і таблиця 1), що за найбільшої різниці температур внутрішнього і припливного повітря $\Delta t_{\Pi}=6,0^{\circ} \mathrm{C} \epsilon$ найвищі значення ексергетичного ККД $\eta_{\mathrm{e}}$. А це значить, що за певної температури зовнішнього повітря $t_{3}$ різницю температур внутрішнього $t_{\mathrm{B}}$ i припливного $t_{\text {п }}$ повітря $\Delta t_{\text {п }}$ за можливості потрібно приймати максимальною. Тому вибрану систему кондиціювання повітря бажано використовувати за вищого коефіцієнта трансформації EER ï холодильної машини та вищої різниці температур внутрішнього і припливного повітря за різних температур зовнішнього повітря, що дасть можливість отримати найвищий ексергетичний ККД $\eta_{\mathrm{e}}$, a значить отримати економічно найвигідніший варіант використання вибраної системи кондиціювання повітря.

Варто звернути увагу (рисунок 3), що за температури зовнішнього повітря $t_{3}$ від 26 до $34^{\circ} \mathrm{C}$ маємо один закон зміни ексергетичного ККД $\eta_{\mathrm{e}}$, a за температури зовнішнього повітря $t_{3}$ від 34 до $42^{\circ} \mathrm{C}$ - інший. Це пояснюється тим, що температура внутрішнього повітря у чистому приміщенні приймається по-різному до температури зовнішнього повітря $t_{3}=30^{\circ} \mathrm{C}$ і вище неї.

Залежності, наведені на рисунку 3 і у таблиці 1, отримані нами у вигляді аналітичних формул для температури зовнішнього повітря $t_{3}=26$ $34^{\circ} \mathrm{C}$ :

$$
\begin{gathered}
\eta_{\mathrm{e}}=0,0195 \cdot t_{3} \cdot E E R-0,4580 \cdot E E R+ \\
+0,0328 \cdot t_{3}-0,7331
\end{gathered}
$$

а для $t_{3}=34-42^{\circ} \mathrm{C}$ :

$$
\begin{gathered}
\eta_{\mathrm{e}}=0,0328 \cdot t_{3} \cdot E E R-0,9093 \cdot E E R+ \\
+0,0644 \cdot t_{3}-1,8063 .
\end{gathered}
$$

Максимальна похибка розрахунків за формулою (7) становить 8,0\% і за формулою (8) - 7,5\%.

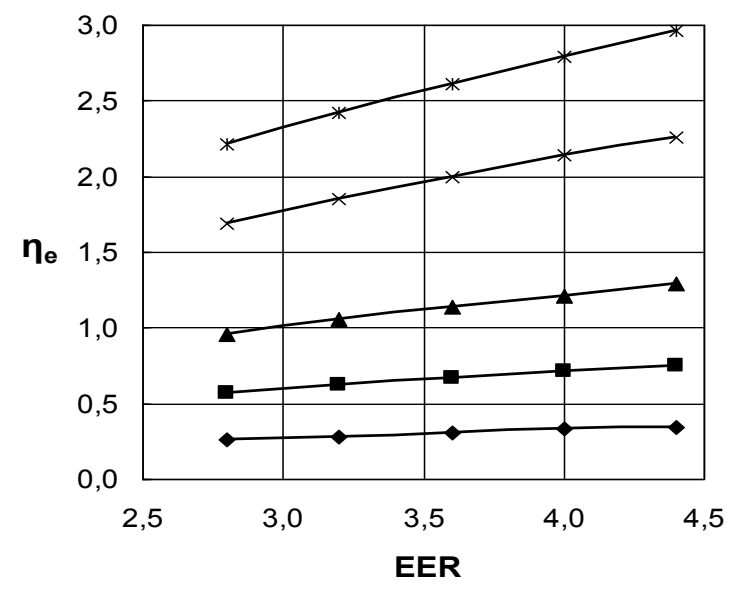

Рисунок 3 - Залежність ексергетичного ККД $\eta_{\mathrm{e}}$ иенттральної прямотечійної СКП чистого приміщення від коефіuієнта трансформації EER ХМ і умов проведення досліджень:

1 ряд - $t_{3}=26^{\circ} \mathrm{C} ; \varphi_{3}=49 \% ; t_{\mathrm{B}}=23^{\circ} \mathrm{C}$; $\varphi_{\mathrm{B}}=50 \% ; \Delta t_{\Pi}=1,5^{\circ} \mathrm{C}$;

2 ряд - $-30 ; 43 ; 26 ; 50 ; 2,5$;

3 ряд А - 34; 38; 27; 50; 3,5;

4 ряд $\mathrm{x}-38 ; 32 ; 28 ; 50 ; 5,0$;

\begin{tabular}{|c|c|c|c|c|c|}
\hline \multirow{3}{*}{$E E R$} & \multicolumn{5}{|c|}{ Умови проведення досліджень } \\
\hline & $\begin{array}{l}t_{3}=26^{\circ} \mathrm{C} \\
\varphi_{3}=49 \% \\
t_{\mathrm{B}}=23^{\circ} \mathrm{C} ; \\
\varphi_{\mathrm{B}}=50 \% ; \\
\Delta t_{\Pi}=1,5^{\circ} \mathrm{C}\end{array}$ & $\begin{array}{l}t_{3}=30^{\circ} \mathrm{C} ; \\
\varphi_{3}=43 \% ; \\
t_{\mathrm{B}}=26^{\circ} \mathrm{C} ; \\
\varphi_{\mathrm{B}}=50 \% ; \\
\Delta t_{\Pi}=2,5^{\circ} \mathrm{C}\end{array}$ & $\begin{array}{l}t_{3}=34^{\circ} \mathrm{C} ; \\
\varphi_{3}=38 \% ; \\
t_{\mathrm{B}}=27^{\circ} \mathrm{C} ; \\
\varphi_{\mathrm{B}}=50 \% ; \\
\Delta t_{\Pi}=3,5^{\circ} \mathrm{C}\end{array}$ & $\begin{array}{l}t_{3}=38^{\circ} \mathrm{C} ; \\
\varphi_{3}=32 \% ; \\
t_{\mathrm{B}}=28^{\circ} \mathrm{C} ; \\
\varphi_{\mathrm{B}}=50 \% ; \\
\Delta t_{\Pi}=5,0^{\circ} \mathrm{C}\end{array}$ & $\begin{array}{l}t_{3}=42{ }^{\circ} \mathrm{C} ; \\
\varphi_{3}=29 \% ; \\
t_{\mathrm{B}}=30^{\circ} \mathrm{C} ; \\
\varphi_{\mathrm{B}}=50 \% ; \\
\Delta t_{\Pi}=6,0^{\circ} \mathrm{C}\end{array}$ \\
\hline & $\eta_{\mathrm{e}}, \%$ & $\eta_{\mathrm{e}}, \%$ & $\eta_{\mathrm{e}}, \%$ & $\eta_{\mathrm{e}}, \%$ & $\eta_{\mathrm{e}}, \%$ \\
\hline 2,8 & 0,26 & 0,57 & 0,96 & 1,69 & 2,21 \\
\hline 3,2 & 0,28 & 0,62 & 1,06 & 1,85 & 2,42 \\
\hline 3,6 & 0,31 & 0,67 & 1,14 & 2,0 & 2,61 \\
\hline 4,0 & 0,33 & 0,71 & 1,21 & 2,14 & 2,79 \\
\hline 4,4 & 0,34 & 0,75 & 1,29 & 2,26 & 2,96 \\
\hline
\end{tabular}

5 ряд $\times-42 ; 29 ; 30 ; 50 ; 6,0$

Таблиця 1 - Залежність ексергетичного ККД $\eta_{\mathrm{e}}$ центральної прямотечійної СКП чистого приміщення від коефіцієнта трансформації EER XM 
Значить ексергетичний аналіз центральної прямотечійної системи кондиціювання повітря чистого приміщення виконаний на створеній авторами інноваційній математичній дослідницькій моделі дав можливість грунтовно оцінити залежності ексергетичного ККД $\eta_{\mathrm{e}}$ цієї системи від коефіцієнта трансформації $E E R$ iї холодильної машини за різних параметрів зовнішнього $\left(t_{3}, \varphi_{3}\right)$ i внутрішнього $\left(t_{\mathrm{B}}, \varphi_{\mathrm{B}}\right)$ повітря та різниці темпеpaтур $\Delta t_{\text {п }}$ внутрішнього і припливного повітря.

\section{IV. ВИСНОВКИ}

Використана інноваційна математична дослідницька модель центральної прямотечійної системи кондиціювання повітря чистого приміщення, що дає можливість комп'ютерного оцінювання iㅣ енергоефективності на основі ексергетичного ККД $\eta_{\mathrm{e}}$ залежно від різних факторів, що впливають на iii роботу, зокрема коефіцієнта трансформації $E E R$ iii холодильної машини $[19,20]$. Наведено залеж-

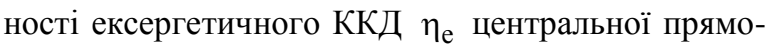
течійної системи кондиціювання повітря чистого приміщення від коефіцієнта трансформації EER іiі холодильної машини за різних параметрів зовнішнього $\left(t_{3}, \varphi_{3}\right)$ і внутрішнього $\left(t_{\mathrm{B}}, \varphi_{\mathrm{B}}\right)$ повітря та різниці температур $\Delta t_{\text {п }}$ внутрішнього і припливного повітря. Показано, що вибрану систему кондиціювання повітря бажано використовувати за вищого коефіцієнта трансформації EER їі холодильної машини та вищої різниці температур внутрішнього і припливного повітря $\Delta t_{\text {п }}$ за різних температур зовнішнього повітря $t_{3}$, що дасть можливість отримати найвищий ексергетичний ККД $\eta_{\mathrm{e}}$, а значить отримати економічно найвигідніший варіант використання вибраної системи кондиціювання повітря.

\section{ЛІТЕРАТУРА}

1. Федотов А.Е. Чистые помещения. Второе изд., перераб. и доп. - М.: АСИНКОМ, 2003. - 576 с.

2. Хаякава И. Чистые помещения. Пер. с японск. - М.: Мир, 1990. - 456 с.

3. Уайт В. Технология чистых помещений. Основы проектирования, испытаний и эксплуатации. М.: Клинрум, 2002. - 304 с.

4. Уайт В. Проектирование чистых помещений. Пер. с англ. - М.: Клинрум, 2004. - 360 с.

5. ГОСТ ИСО 14644-1. Чистые помещения и связанные с ними контролируемые среды. Часть 1. Классификация чистоты воздуха.

6. Соколов Е.Я. Энергетические основы трансформации тепла и процессов охлаждения: учеб. пособие для вузов.- 2-е изд., перераб. / Е.Я. Соколов, В.М. Бродянский. - М.: Энергоиздат, 1981. $320 \mathrm{c}$.
7. Шаргут Я. Эксергия / Я. Шаргут, Р. Петела. М.: Энергия, 1968. - 280 с.

8. Эксергетические расчеты технических систем: справ. пособие / [В.М. Бродянский, Г.П. Верхивкер, Я.Я. Карчев и др.]; под ред. А.А. Долинского, В.М. Бродянского; Ин-т технической теплофизики АН УССР. - Киев: Наук. думка, 1991. $-360 \mathrm{c}$.

9. Бродянский В.М. Эксергетический метод термодинамического анализа / В.М. Бродянский. М.: Энергия, 1973. - 296 с.

10.Бэр Г.Д. Техническая термодинамика / Г.Д. Бэр. - М.: Мир, 1977. - 518 с.

11. Богословский В.Н. Кондиционирование воздуха и холодоснабжение: Учебник для вузов / В.Н. Богословский, О.Я. Кокорин, Л.В. Петров. Стройиздат, 1985. - 367 с.

12. Прохоров В.И. Метод вычисления эксергии потока влажного воздуха / В.И. Прохоров, С.М. Шилклопер // Холодильная техника. - 1981, № 9. C. 37-41.

13. Шилклопер С.M. Эксергетический анализ систем обеспечения микроклимата и энергоснабжения / С.М. Шилклопер, С.И. Жадин // Строительство и архитектура. Сер. 9. - 1982, вып. 4. C. $18-27$.

14. СНиП 2.04.05-86. Отопление, вентиляция и кондиционирование. - М.: ЦИТП Госстроя СССР, 1987. - 64 с.

15.Янтовский Е.И. Потоки энергии и эксергии / Е.И. Янтовский. - М.: Наука, 1988. - 144 с.

16. Bes T. Egzergia w procesach ogrzewania, klimatyzacji i suszenia / T. Bes // Energetyka Przemysłowa. - 1962. 10, № 11. - S. 388-392.

17. Labaj Włodzimierz. Efektywność egzergetyczna autonomicznych klimatyzatorów miejscowych / Włodzimierz Łabaj, Oksana Omelczuk // XIV Konferencja ciepłowników „Perspektywy rozwoju ciepłownictwa". Materiały konferencyjne. - Solina: Politechnika Rzeszowska, 26-28 września 2002 r. S. 137-144.

18. Лабай Володимир. Ексергетична ефективність центральних кондиціонерів / Володимир Лабай, Тарас Іванух // V Konferencja naukowa RzeszowskoLwowsko-Koszycka „Aktualne problemy budownictwa i inżynierii środowiska”. Zeszyty naukowe Politechniki Rzeszowskiej «Budownictwo i inżynieria środowiska». - Z. 32, część 2: Inżynieria Środowiska. - Rzeszów: Politechnika Rzeszowska, 25-26 września 2000 r. - S. 229-235.

19. Лабай В.Й. Дослідження ексергетичної ефективності систем кондиціювання повітря чистих приміщень / В.Й. Лабай, Д.І. Гарасим//Науковотехнічний журнал «Холодильна техніка та технологія», №4(150). - Одеса: ОНАХТ, 2014. C. 47-53.

20. Labay V. Innovation model for energy effective investigations of air conditioning systems for cleanrooms / V. Labay, D. Harasym // ECONTECHMOD Lublin-Rzeszow: 2014 - Vol. 3, № 1. - P. 47-52. 
V.Y. Labay, D.I. Harasym

Lviv Polytechnic National University, 12 St. Bandery str., Lviv, 79013, Ukraine

\section{INFLUENCE OF COEFFICIENT OF TRANSFORMATION OF REFRIGERATION MACHINE ON EXERGETIC OUTPUT-INPUT RATIO OF AIR CONDITIONING SYSTEM FOR CLEAN- ROOM}

Exergetic method is a universal way of thermodynamic research of various processes of energy transformation in energy technological systems, to which air conditioning system for cleanroom belongs. Implementation of exergetic analysis for energy technological system makes it possible to determine the influence of various elements of its system on its work and because of this to increase the effectiveness of work of energy technological system in general.

Effectiveness of work of any air conditioning system depends on energy effectiveness of refrigeration machine, which serves it and consumes electricity for reducing the heat of supply air which enters the room. And it means that the main purpose of selection of certain refrigeration machine for air conditioning system is to reach the maximum cooling capacity with minimum energy consumption.

Innovation mathematical research model of the central straight flow air conditioning system for cleanroom in order to computer estimation of its energy effectiveness by virtue of exergetic output-input ratio depending on different factors, which have influence on its work, in particular the coefficient of transformation EER of its refrigeration machine was used in this article. The dependences of exergetic output-input ratio $\eta_{\mathrm{e}}$ of chosen air conditioning system for cleanroom on coefficient of transformation EER of its refrigeration machine by different parameters of outdoor and indoor air and the temperature difference between the indoor and supply air were presented. It is shown, that the chosen air conditioning system should be preferably used by higher coefficient of transformation EER of its refrigeration machine and higher difference between temperatures of indoor and supply air by various temperatures of outdoor air, that will give the opportunity to gain the highest exergetic outputinput ratio $\eta_{\mathrm{e}}$, which means to gain the most advantageous economical variant of exploitation of chosen air conditioning system.

Keywords: Exergetic balance - Air conditioning systems - Cleanrooms - Exergetic efficiency - Coefficient of transformation EER

\section{REFERENCES}

1. Fedotov A.E. 2003. Chistye pomeshcheniia. Vtoroe izd., pererab. i dop. - Moskva: ASINKOM, 2003. - 576 (in Russian).

2. Hayakava I. 1990. Chistye pomeshcheniia. Per. s iaponsk. - Moskva: Mir. - 456 (in Russian).

3. Whyte W. 2002. Tekhnologiia chistykh pomeshchenii. Osnovy proektirovaniia, ispytanii i ekspluatatsii. - Moskva: Klinrum. - 304 (in Russian).

4. Whyte W. 2004. Proektirovanie chistykh pomeshchenii. Per. s angl. - Moskva: Klinrum. - 360 (in Russian).

5. GOST ISO 14644-1. Chistye pomeshcheniia i sviazannye s nimi kontroliruemye sredy. Chast' 1 . Klassifikatsiia chistoty vozdukha (in Russian).

6. Sokolov E.Ia. 1981. Energeticheskie osnovy transformatsii tepla i protsessov okhlazhde-niia: ucheb. posobie dlia vuzov. - 2-e izd., pererab. / E.Ia. Sokolov, V.M. Brodianskii. - Moskva: Energoizdat. 320 (in Russian).

7. Shargut Ia. 1968. Eksergiia / Ia. Shargut, R. Petela. - Moskva: Energiia. - 280 (in Russian).

8. Eksergeticheskie raschety tekhnicheskikh sistem. 1991: sprav. posobie / [V.M. Brodianskii, G.P. Verhivker, Ia.Ia. Karchev i dr.]; pod red. A.A. Dolinskogo, V.M. Brodianskogo; In-t tekhnicheskoi teplofiziki AN USSR. - Kiev: Nauk. dumka. - 360.
9. Brodianskii V.M. 1973. Eksergeticheskii metod termodinamicheskogo analiza / V.M. Brodianskii. Moskva: Energiia. - 296 (in Russian).

10.Ber G.D. 1977. Tekhnicheskaia termodinamika / G.D. Ber. - Moskva: Mir. - 518 (in Russian).

11.Bogoslovskii V.N. 1985. Konditsionirovanie vozdukha i kholodosnabzhenie: Uchebnik dlia vuzov / V.N. Bogoslovskii, O.Ia. Kokorin, L.V. Petrov. Stroiizdat. - 367 (in Russian).

12.Prokhorov V.I. 1981. Metod vychisleniia eksergii potoka vlazhnogo vozdukha / V.I. Prokhorov, S.M. Shilkloper // Kholodil'naia tekhnika. - № 9. - 37-41 (in Russian).

13.Shilkloper S.M. 1982. Eksergeticheskii analiz sistem obespecheniia mikroklimata i energosnabzheniia / S.M. Shilkloper, S.I. Zhadin // Stroitel'stvo i arkhitektura. Ser. 9. - Vyp. 4. - 18-27 (in Russian).

14.SNiP 2.04.05-86. 1987. Otoplenie, ventiliatsiia i konditsionirovanie. - Moskva: TsITP Gosstroia SSSR. - 64 (in Russian).

15.Iantovskii E.I. 1988. Potoki energii i eksergii / E.I. Iantovskii. - Moskva: Nauka. - 144 (in Russian).

16.Bes T. 1962. Egzergia $w$ procesach ogrzewania, klimatyzacji i suszenia / T. Bes // Energetyka Przemysłowa. - 10, № 11. - 388-392 (in Polish).

17.Labaj Włodzimierz. 2002. Efektywność egzergetyczna autonomicznych klimatyzatorów miejscowych / Włodzimierz Łabaj, Oksana Omelczuk 
// XIV Konferencja ciepłowników „Perspektywy rozwoju ciepłownictwa”. Materiały konferencyjne. Solina: Politechnika Rzeszowska, 26-28 września. 137-144 (in Ukrainian).

18.Labai Volodymyr. 2000. Eksergetychna efektyvnist' tsentral'nykh kondytsioneriv / Volodymyr Labai, Taras Ivanukh // V Konferencja naukowa Rzeszowsko-Lwowsko-Koszycka „Aktualne problemy budownictwa i inżynierii środowiska”. Zeszyty naukowe Politechniki Rzeszowskiej «Budownictwo i inżynieria środowiska». - Z. 32, część 2: Inżynieria Środowiska. - Rzeszów: Politechnika Rzeszowska, 25-26 września. - 229-235 (in Ukrainian).
19.Labay V.Y., Harasym D.I. 2014. Research of exergy efficiency of air conditioning systems for cleanrooms. Kholodylna Tekhnika ta Tekhnologiya [Refrigeration Engineering and Technology], No.4(150), 47-53 (in Ukrainian). doi: 10.15673/0453-8307.4/2014.28053

20.Labay V. 2014. Innovation model for energy effective investigations of air conditioning systems for cleanrooms / V. Labay, D. Harasym // ECONTECHMOD - Lublin-Rzeszow: 2014 - Vol. 3, № 1. 47-52 (in English).

Отримана в редакції 12.01.2015, прийнята до друку 03.03.2015 